\title{
Distribution of inorganic and total arsenic in tissues of the marine gastropod Hemifusus ternatanus
}

\author{
D. J. H. Phillips ${ }^{1} \&$ M. H. Depledge ${ }^{2}$ \\ ${ }^{1}$ Environmental Protection Department, Empire Centre, Tsim Sha Tsui East, Kowloon, Hong Kong \\ ${ }^{2}$ Department of Physiology, University of Hong Kong, Sassoon Road, Hong Kong
}

\begin{abstract}
The spindle shell Hemifusus ternatanus (Gmelin) may accumulate large quantities of arsenic in its tissues, exhibiting on occasion concentrations of total arsenic exceeding $100 \mu \mathrm{g} \mathrm{g}^{-1}$ wet weight. Investigation of the distribution of total and inorganic arsenic in tissues of this species has revealed that the majority of the body load arsenic is present in the soft parts, as opposed to the operculum and shell. The gill in particular exhibits very high concentrations of arsenic, much of which is present in the inorganic form. It is probable that arsenic is taken up by $H$. ternatanus both from seawater and food; biotransformation of accumulated inorganic arsenic may occur in the gill and possibly other tissues also. The foot - that portion of the animal most commonly eaten by Man generally contains only moderate concentrations of total arsenic and low levels of inorganic forms of the element. Ingestion of tissues other than the foot may represent a toxicological hazard, particularly in the case of the gill.
\end{abstract}

\section{INTRODUCTION}

The toxic threat to higher organisms posed by arsenic in seafood depends largely on the chemical speciation of the arsenic present in the tissues of the marine products ingested. It is generally believed that inorganic forms of arsenic are of greatest toxicity. The organic forms of the element present in marine organisms (arseno-sugars, arsenolipids, arsenobetaine, arsenocholine and possibly others; see Phillips \& Depledge 1985) are much less toxic (e. g. Kaise et al. 1985), and arsenic ingested with seafood by Man is rapidly cleared in the urine (Chapman 1926, Coulson et al. 1935, Freeman et al. 1979, Foà et al. 1984). The elucidation of comparative levels of inorganic and organic forms of arsenic in marine products is thus of considerable importance from a toxicological viewpoint. In addition, such studies provide an insight into the kinetics of arsenic and its compounds in both individual species and the biosphere as a whole.

Phillips et al. (1982) reported unusually high concentrations of total arsenic in the spindle shells Hemifusus tuba and $H$. ternatanus. These large marine gastropods are fished commercially by trawlers operating from Hong Kong. They live in or on sediment at water depths of greater than $20 \mathrm{~m}$, and prey upon bivalve molluscs (Hamada 1974, Morton 1985). H. ternatanus is the larger of the 2 species, growing to shell lengths of over $40 \mathrm{~cm}$. No precise statistics are available for landings of spindle shells locally, but it is estimated that at least 20 tonnes (in-shell weight) of the 2 species is marketed annually in Hong Kong (Phillips unpubl. data). The local population consider the flesh of Hemifusus spp. a luxury; generally the muscular foot is eaten, but sometimes the viscera are also used in preparing soups.

This paper presents data on the distributions of total and inorganic arsenic in the tissues of Hemifusus ternatanus (Gmelin), which accounts for the majority of local landings of Hemifusus species.

\section{MATERIALS AND METHODS}

Individual Hemifusus ternatanus were purchased at retail markets in Hong Kong (specimens HT1 to HT5) or were obtained directly from trawler fishermen (HT6 to HT10). They were stored frozen prior to dissection and analysis. When required for analysis, individuals were thawed, their shells carefully broken and the soft 
parts removed intact. After rinsing in distilled deionised water, the tissues (gonad, digestive gland, kidney, gill, foot, 'rest soft parts', operculum and shell) were dissected out using stainless steel instruments. Tissues were homogenised in a Brinkman PT10-35 Polytron Kinematica ultrasonic blender; these are specifically marketed for studies of trace elements and are noncontaminating.

Concentrations of inorganic arsenic in tissue homogenates were determined according to the method of Lunde (1973), which involves the addition of $\mathrm{HCl}$ to $6.6 \mathrm{~N}$ and subsequent removal of inorganic arsenic as $\mathrm{AsCl}_{3}$ by distillation at $100^{\circ} \mathrm{C}$. A similar method was favoured by Brooke \& Evans (1981) and is believed to produce reliable results. Total arsenic concentrations were determined after dry ashing of tissue homogenates, using the method of Penrose et al. (1975), as modified slightly by Langston (1980). Analysis in all cases employed the hydride generation technique. Quality control was provided by spiking of samples and the use of reference materials. Mean total arsenic levels of $3.5 \mu \mathrm{g} \mathrm{g}^{-1}$ dry weight and $14.0 \mu \mathrm{g} \mathrm{g}^{-1}$ dry weight were found for National Bureau of Standards albacore tuna (RM50) and oyster tissue (SRM1566) materials, compared to a recommended value for tuna of $3.3 \pm 0.4 \mu \mathrm{g} \mathrm{g}^{-1}$ and a certified value for oyster of $13.4 \pm 1.9 \mu \mathrm{g} \mathrm{g}^{-1}$. Inorganic arsenic concentrations in these 2 materials averaged $0.04 \mu \mathrm{g} \mathrm{g}^{-1}$ dry weight (tuna) and $0.54 \mu \mathrm{g} \mathrm{g}^{-1}$ dry weight (oyster); the National Bureau of Standards do not quote data for this chemical form in the 2 materials.

\section{RESULTS}

Table 1 presents concentrations of total and inorganic arsenic in Hemifusus ternatanus purchased at retail markets in Hong Kong. Tissue wet weights and ratios of inorganic to total arsenic are also shown. All concentration data are quoted on a wet tissue basis to facilitate comparison of the levels found with public health regulations, which are also based on wet weights of seafoods. Similar data for $H$. ternatanus obtained directly from fishermen are shown in Table 2. These results have been used to generate pie diagrams of the contents of total and inorganic arsenic in each tissue relative to the whole animal (Fig. $1 \& 2$ ).

Levels of total arsenic in the tissues differed considerably between individuals; total contents varied from $2509 \mu \mathrm{g}$ in HT9 to $34460 \mu \mathrm{g}$ in HT2. However, total arsenic concentrations in the tissues generally decreased in the same relative order, as follows: gill $\gg$ rest soft parts $\approx$ digestive gland $\geqslant$ kidney $>$ foot $\approx$ gonad $\gg$ operculum $>$ shell.

In contrast to the profile exhibited by total arsenic,

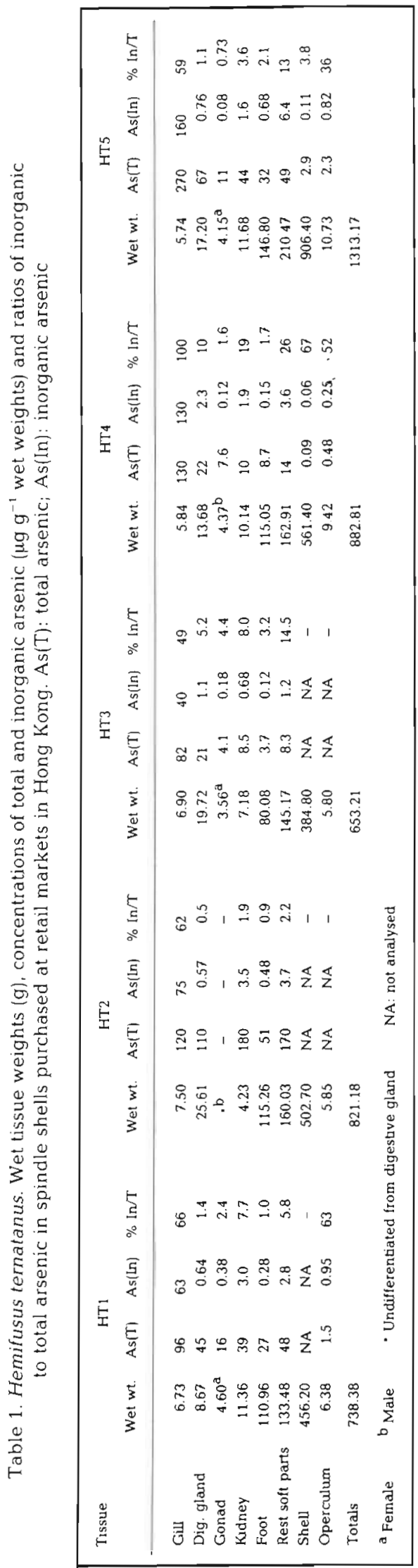




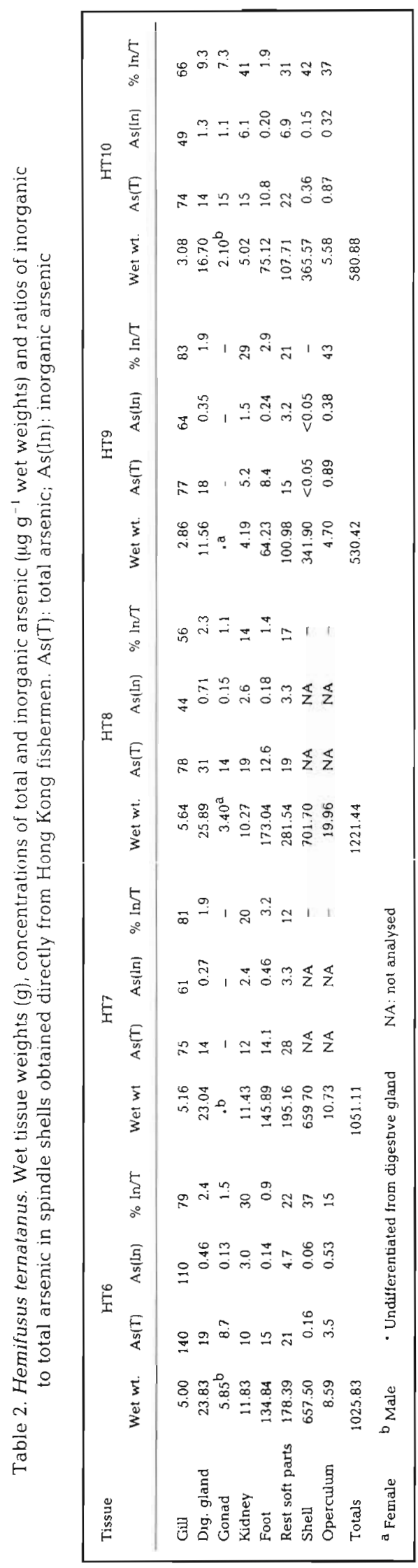

the levels of inorganic arsenic found in $H$. ternatanus varied little between individuals, extreme values for arsenic contents being $487 \mu \mathrm{g}$ (HT3) and $2514 \mu \mathrm{g}$ (HT5). Concentrations of inorganic arsenic in the tissues decreased in a similar fashion in most individuals, as follows: gill $\geqslant$ rest soft parts $\approx$ kidney $\geqslant$ digestive gland $\geqslant$ operculum $\geqslant$ gonad $\geqslant$ foot $>$ shell.

Of particular note in these data is the divergence in arsenic levels between the hard and soft tissues. The heavily calcified shell of Hemifusus ternatanus accounted for about $60 \%$ of the total weight of the animal, but contained little arsenic in any form. The chitinous operculum also exhibited low concentrations of total arsenic, although its inorganic arsenic content was higher than that of the shell. The gill accounted for about $2 \%$ of the weight of the soft parts and generally less than $1 \%$ of the total animal weight, but this tissue commonly contained a large proportion of the total arsenic present and a very large percentage of the overall content of inorganic arsenic in each individual (the latter sometimes exceeding $50 \%$; see Fig. 1 \& 2).

The percentage of total arsenic present in inorganic form varied with the absolute amounts of total arsenic present in the individual. Heavily contaminated individuals (e.g. HT2, HT5) exhibited low ratios of inorganic to total arsenic in all soft tissues other than the gill. Less contaminated individuals (e.g. HT9, HT10) exhibited higher ratios of inorganic to total arsenic. This ratio also varied consistently between the tissues, decreasing as follows: gill $>$ shell $\approx$ operculum $>$ kidney $\approx$ rest soft parts $>$ digestive gland $\approx$ gonad $\geqslant$ foot.

\section{DISCUSSION}

Several authors have reported that wet digestions, with a variety of acid mixtures, fail to completely oxidise certain particularly refractory forms of organic arsenic in marine samples, and thus underestimate the concentrations of total arsenic in these materials. No such differences were found in the present study in comparisons of dry ashing with nitric/sulphuric/perchloric acid digestions. This may be because Hemifusus ternatanus does not contain unusually stable organic arsenic derivatives (cf. marine teleosts, for example). The present studies nevertheless employed the dry ashing technique for routine analysis. There is a need for further investigations of the chemical speciation of arsenic in seafoods, particularly in respect of the identification of arsenic compounds which are unusually difficult to oxidise by acid digestion.

This report confirms and extends previous observations of Phillips et al. (1982) that Hemifusus ternatanus may exhibit high concentrations of total arsenic. Indi- 


\section{TOTAL ARSENIC}

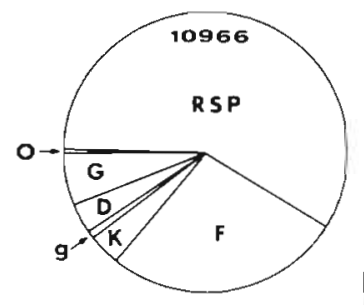

HT1

INORGANIC ARSENIC

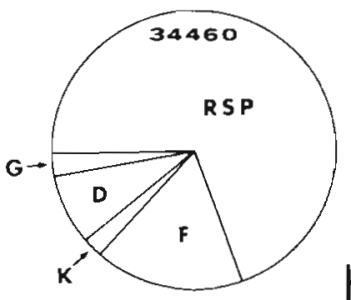

$\mathrm{HT} 2$

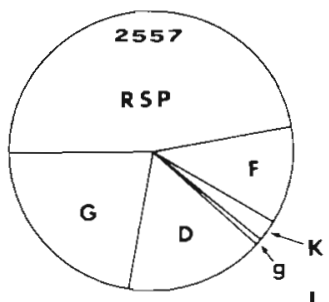

HT3
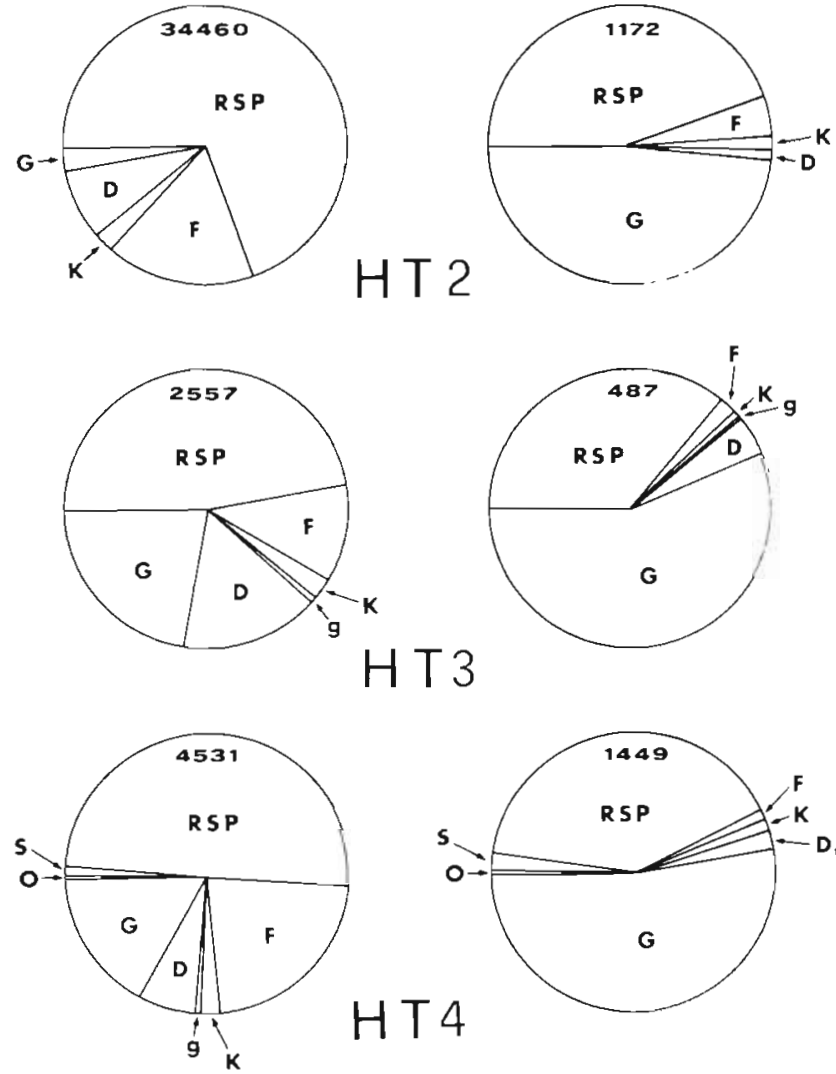

HT 4
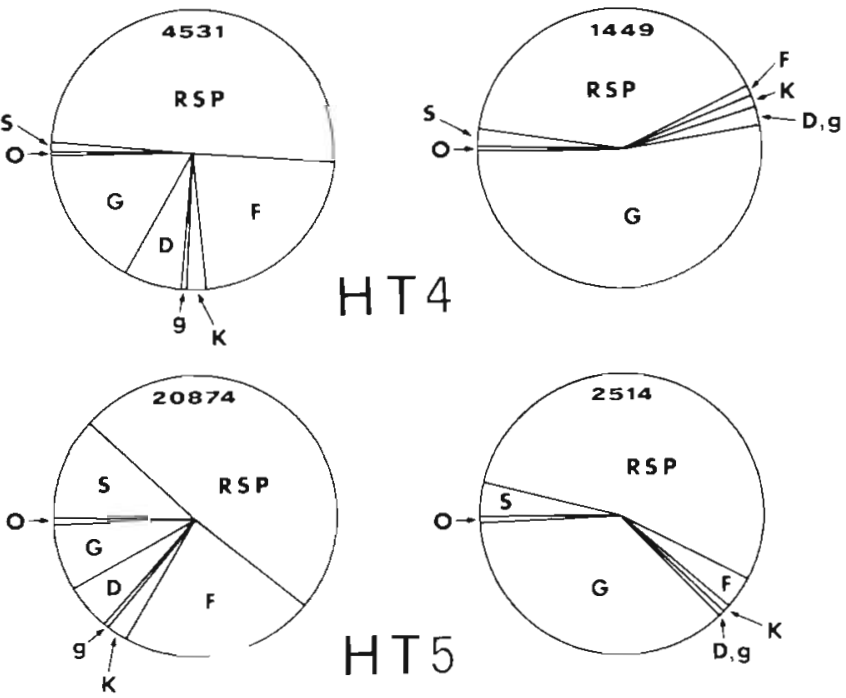

HT 5

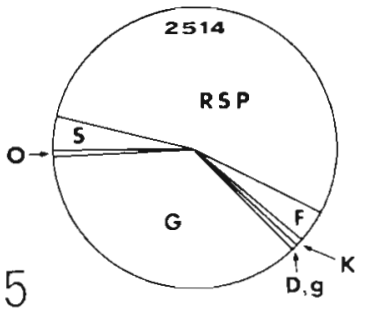

Fig. 1. Hemifusus tematanus. Pie diagrams showing the relative contributions of each tissue to the total and inorganic arsenic contents of different individual spindle shells from retail markets in Hong Kong. Total content $(\mu \mathrm{g})$ shown at the top of each figure. G: gill; D: digestive gland; g: gonad; K: kidney; F: foot; RSP: rest soft parts; S: shell; O: operculum

\section{TOTAL ARSENIC \\ INORGANIC ARSENIC}
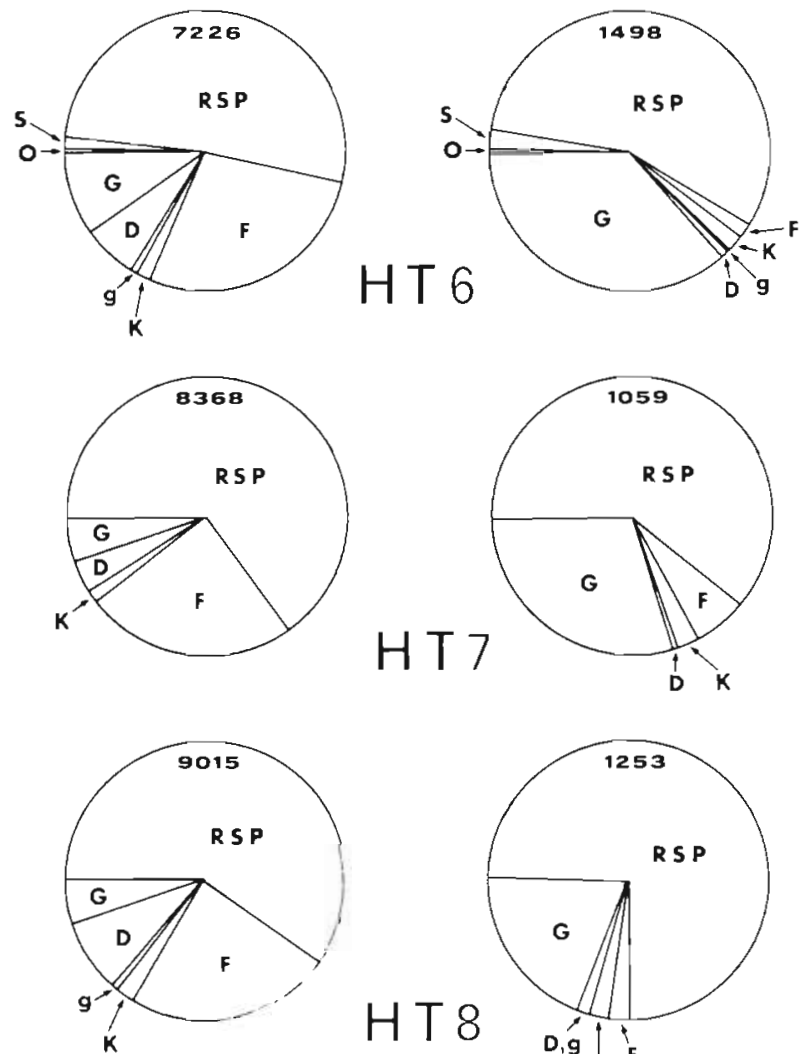

HT 8
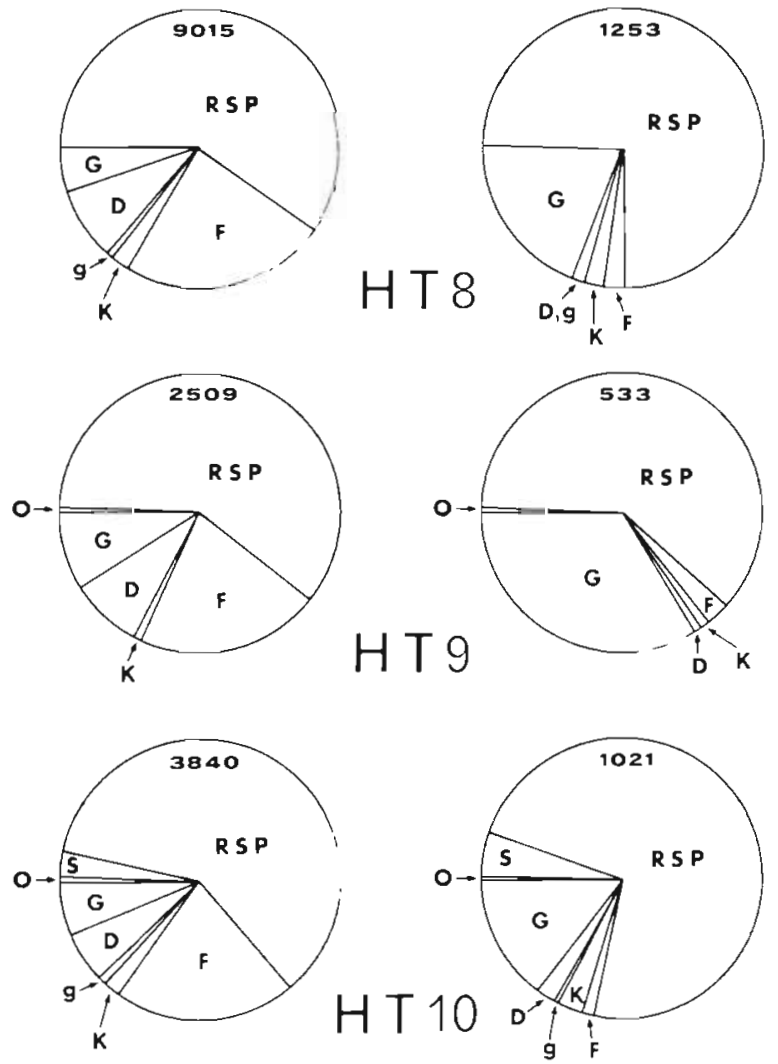

Fig. 2. Hemifusus ternatanus. Pie diagrams showing the relative contributions of each tissue to the total inorganic arsenic contents of different individual spindle obtained from Hong Kong fishermen. Layout and symbols as for Fig. 1 
viduals analysed in the present study varied considerably in their degree of contamination by arsenic, but concentrations greater than $100 \mu \mathrm{g} \mathrm{g}^{-1}$ wet weight (equivalent to about $500 \mu \mathrm{g} \mathrm{g}^{-1}$ dry weight) were recorded in some individuals and several tissues, notably the gill. While not as great as the arsenic levels reported for the polychaete Tharyx marioni (usually over $2000 \mu \mathrm{g} \mathrm{g}^{-1}$ dry weight on a whole body basis; see Gibbs et al. 1983), these concentrations are unusual for gastropods, and also for molluscs in general (e. g. Eisler 1981, M.A.F.F. 1982, Shiomi et al. 1984, Maher 1985). Shiomi et al. (1984) suggested that carnivorous gastropods tend to accumulate more arsenic than herbivorous members of this group. Both $H$. ternatanus and $H$. tuba feed on bivalve molluscs (Hamada 1974, Morton 1985), although they exhibit different dietary preferences (B. S. Morton pers. comm.). H. ternatanus prefers to feed upon members of the family Pinnidae; this family is represented locally by 3 species of the genus Pinna and 4 species of the genus Atrina (Morton \& Morton 1983). Species of Pinna have been reported by Papadopoulou (1973) and Maher (1985) to contain appreciable quantities of total arsenic, and it is probable that local $H$. ternatanus derive a significant proportion of their total arsenic load from their diet. However, the very high concentrations of arsenic in the gill of $H$. ternatanus also imply the possibility of uptake of the element from solution, either from the water column close to the substrate (when the shell is crawling thereon) or from interstitial waters when burrowing. Phillips \& Depledge (1986) have demonstrated that $H$. tuba accumulates arsenic from arsenate in solution; it is probable that $H$. ternatanus does likewise. Variations in exact prey items with site and variations in bioavailable arsenic concentrations in solution with site are likely to be responsible for the differences in absolute concentrations of arsenic and its tissue distribution between individuals analysed in the present study. However, firm conclusions are not possible with respect to differences between sites in overall arsenic bio-availability, as the locations at which the retail market samples were captured are unknown.

Several authors have published data on the ratio of inorganic arsenic to total arsenic in marine organisms. This ratio is usually greater in macroalgae than in organisms of higher trophic levels. This may imply either a basic difference between plants and animals in arsenic kinetics (see Maher 1983, Phillips \& Depledge 1985), or the biotransformation of arsenic as it moves through the food chain. Even among algae, however, very considerable differences exist between species. Brown algae of most genera contain relatively low amounts of inorganic arsenic compared to total arsenic (Lunde 1973, Sanders 1979, Shinagawa et al. 1983), although some members of the family Sar- gassaceae exhibit high ratios of these 2 forms (Johnson \& Braman 1975). Principal among these is Hizikia fusiforme, which contains about $60 \%$ of its total arsenic in the inorganic form (Shinagawa et al. 1983, Whyte \& Englar 1983). Red and green algae may also exhibit high contents of inorganic arsenic (Sanders 1979)

Amongst higher organisms, it is rare to find significant percentages of total arsenic in the inorganic form. Almost all species studied to date exhibit ratios of inorganic arsenic:total arsenic of $10 \%$ or less (Lunde 1973, 1977, Reinke et al. 1975, Brooke \& Evans 1981, Flanjak 1982, Shinagawa et al. 1983, Maher 1983, Shiomi et al. 1984, Norin et al. 1985). This may be a reflection of the high toxicity of inorganic arsenic, i. e. infer the presence of detoxification mechanisms in higher organisms, based on the synthesis of organic forms of arsenic with reduced toxicity. The discovery of very high ratios of inorganic:total arsenic in the gill of Hemifusus ternatanus (40 to $100 \%$; mean $68 \%$ ) is therefore intriguing. It is possible that inorganic arsenic taken up from solution by the gill is biotransformed in the gill and/or other tissues of the spindle shell. The kidney (which exhibits a moderate proportion of inorganic arsenic compared to total arsenic levels) may be involved in such biotransformation. The high inorganic arsenic contents associated with the 'rest soft parts' fraction of $H$. ternatanus tissues are believed to be present mainly in the osphradium, which is a gill-like structure involved in osmotic regulation in this species. Additional dissection of the rest soft parts' fraction into composites containing muscle tissue or tissues including the osphradium (Phillips unpubl. data) prior to analysis supports this concept. However, the osphradium is very small even in large individuals of $H$. ternatanus, and its analysis as a single tissue presents practical problems.

The concept that Hemifusus ternatanus controls its overall content of inorganic arsenic by biotransforming part of the body load of the element to organic derivatives is supported by the low variability of inorganic arsenic concentrations between individuals of this species. Thus, variations in total arsenic between different individuals are caused principally by larger or smaller body loads of organic arsenic derivatives, which are assumed to be less toxic to both the organism itself and to higher consumers upon its ingestion.

Finally, the implications of these data in respect of public health deserve some mention. The foot of Hemifusus ternatanus is that tissue most commonly eaten by Man. Ratios of inorganic:total arsenic in the foot are very low (0.9 to $3.2 \%)$, and absolute concentrations of inorganic arsenic in the foot ranged between 0.12 and $0.68 \mu \mathrm{g} \mathrm{g}^{-1}$ wet weight in the samples studied. Most public health regulations permit a 
concentration of at least $1.0 \mu \mathrm{g} \mathrm{g}^{-1}$ wet weight as inorganic arsenic; thus the ingestion of the foot is unlikely to create a toxic threat to the consumer. However, the ingestion of soups in which the viscera have been used is of greater concern. If the gill is eaten, or if the inorganic arsenic present in the gill and certain other tissues is solubilised by the cooking method, significant quantities of this form of the element could be ingested. This might represent a toxicological hazard to consumers in the long term.

Acknowledgements. The technical assistance of Dr. E. Y. L. Chan, Mr. K. K. So, and Mr S. T. Chan and his staff is gratefully acknowledged.

\section{LITERATURE CITED}

Brooke, P. J., Evans, W. H. (1981), Determination of total inorganic arsenic in fish, shellfish and fish products. Analyst 106: 514-520

Chapman, A. (1926). The presence of compounds of arsenic in marine crustaceans and shellfish. Analyst 51:548-563

Coulson, E. J., Remington, R. E., Lynch, K. M. (1935). Metabolism in the rat of the naturally occurring arsenic of shrimp as compared with arsenic trioxide. J. Nutr. 10: 255-270

Eisler, R. (1981). Trace metal concentrations in marine organisms. Pergamon Press, New York

Flanjak, J. (1982). Inorganic and organic arsenic in some commercial east Australian Crustacea. J. Sci. Fd Agric. 33: $579-583$

Foà, V., Colombi, A., Maroni, M., Buratti, M., Calzaferri, G. (1984). The speciation of the chemical forms of arsenic in the biological monitoring of exposure to inorganic arsenic. Sci. Total Environ 34: 241-259

Freeman, H. C., Uthe, J. F., Fleming, R. B., Odense, P. H., Ackman, R. G., Landry, G., Musial, C. (1979). Clearance of arsenic ingested by Man from arsenic contaminated fish. Bull. environ. Contam. Toxicol. 22: 224--229

Gibbs, P. E., Langston, W. J., Burt, G. R., Pascoe, P. L. (1983). Tharyx marioni (Polychaeta): a remarkable accumulator of arsenic. J. mar. Biol. Ass. U. K. 63: 313-325

Hamada, S. (1974). Growth and feeding of Hemifusus ternatanus in early crawling stage. Venus 33: 75-79

Johnson, D. L., Braman, R. S. (1975). The speciation of arsenic and the content of germanium and mercury in members of the pelagic Sargassum community. Deep Sea Res. 22: 503-507

Kaise, T. Watanabe, S., Itoh, K. (1985). The acute toxicity of arsenobetaine. Chemosphere 14:1327-1332

Langston, W. J. (1980). Arsenic in U. K. estuarine sediments and its availability to benthic organisms. J. mar biol. Ass. U. K. 60 : 869-881
Lunde, G. (1973). Separation and analysis of organic-bound and inorganic arsenic in marine organisms. J. Sci. Fd Agric. 24: 1021-1027

Lunde, G. (1977). Occurrence and transformation of arsenic in the marine environment. Environ. Hlth. Perspect. 19: $47-52$

M.A.F.F. (1982). Survey of arsenic in food. Ministry of Agriculture, Fisheries and Food: Food Surveillance Paper No. 8. Her Majesty's Stationery Office, London

Maher, W. A. (1983). Inorganic arsenic in marine organisms. Mar. Pollut. Bull. 14: 308-310

Maher, W. A. (1985). Distribution of arsenic in marine animals: relationship to diet. Comp. Biochem. Physiol. 82C: 433-434

Morton, B. (1985). Prey preference, capture and ration in Hemifusus tuba (Gruelin) (Prosobranchia: Melongenidae). J. exp. mar. Biol. Ecol. 94: 191-210

Morton, B., Morton J. (1983). The sea shore ecology of Hong Kong. Hong Kong University Press, Hong Kong

Norin, H., Vahter, M. Christakopoulos, A., Sandstrom, M. (1985). Concentration of inorganic and total arsenic in fish from industrially polluted water. Chemosphere 14: 325-334

Papadopoulou, C. (1973). The elementary composition of marine invertebrates as a contribution to the sea pollution investigation. Proc. MAMBO meeting, Castellabate, Italy, June 18-22, P. 1-18

Penrose, W. R., Black, R., Hayward, M. J. (1975). Limited arsenic dispersion in sea water, sediments and biota near a continuous source. J. Fish. Res. Bd. Can. 32: 1275-1281

Phillips, D. J. H., Depledge, M. H. (1985). Metabolic pathways involving arsenic in marine organisms: a unifying hypothesis. Mar. Environ. Res. 17: 1-12

Phillips, D. J. H., Depledge, M. H. (1986). Chemical forms of arsenic in marine organisms, with emphasis on Hemifusus species. Water Sci. Technol. 18: 213-222

Phillips, D. J. H., Thompson, G. B., Gabuji, K. M., Ho, C. T (1982). Trace metals of toxicological significance to Man in Hong Kong seafood. Environ. Pollut. Ser. B 3: 27-45

Reinke, J., Uthe, J. F., Freeman, H. C., Johnston, J. R. (1975). The determination of arsenite and arsenate ions in fish and shellfish by selective extraction and polarography. Environ. Lett. 8: 371-380

Sanders, J. G. (1979). The concentration and speciation of arsenic in marine macro-algae. Estuar. coast. mar Sci. 9: 95-99

Shinagawa, A., Shiomi, K., Yamanaka, H., Kikuchi, T. (1983). Selective determination of inorganic arsenic (III), ( $V$ ) and organic arsenic in marine organisms. Bull. Jap. Soc. scient. Fish. 49: 75-78

Shiomi, K., Shinagawa, A., Igarashi, T., Hirota, K., Yamanaka, H., Kikuchi, T. (1984). Contents and chemical forms of arsenic in shellfishes in connection with their feeding habits. Bull. Jap. Soc. scient. Fish. 50: 293-297

Whyte, J. N. C., Englar, J. R. (1983). Analysis of inorganic and organic-bound arsenic in marine brown algae. Botanica mar. 26: 159-164 